\title{
MASALAH KUSTA DAN DISKRIMINASI SERTA STIGMATISASINYA DI INDONESIA
}

\author{
Nuah Perdamenta Tarigan \\ Character Building Development Center, BINUS University \\ Jln. Kemanggisan Ilir III No. 45, Kemanggisan-Palmerah, Jakarta Barat 11480 \\ nuahptarigan@gmail.com
}

\begin{abstract}
By developing an understanding on leprosy issues in social-community perspective, we will be more understanding to leprosy and many others. This is still a paramount in developing and building character especially in leadership context in modern Indonesia society. Good Interpersonal relationship always starts from self awareness, and then it could be developing among the men and women especially marginalized people in our society. Finally we could eliminate stigma and discrimination for people affected by leprosy promptly. The writer used the qualitiative method, with the aim of this research focuses on how to develop Nation Character Building based on our Founding Fathers Vision and make it down to earth to be our daily habits, appreciating and fair enough for every people and avoiding stigma and discrimination to anyone including people with disability and people affected by leprosy.
\end{abstract}

Keywords: leprosy, social-community, interpersonal-relationship, stigma and discrimination for people affected by leprosy

\begin{abstract}
ABSTRAK
Dengan Menggali masalah kusta dari sisi sosial kemasyarakatan, kita akan semakin mengerti betapa masalah kusta dan masalah lainnya masih merupakan masalah yang utama dalam mengembangkan karakter manusia khususnya dalam konteks kepemimpinan didalam masyarakat Indonesia yang semakin maju. Hubungan antar manusia yang baik dimulai dari bagaimana kita mengerti akan keberadaan diri kita sendiri, lalu dalam berhubungan antar sesama khususnya orang-orang yang termarjinalisasi didalam masyarakat kita. Akhirnya kita bisa menghilangkan Stigma dan Diskriminasi terhadap orang yang mengalami Kusta. Metode yang dipakai adalah metoda kualitatif, serta tujuannya adalah membangun Karakter Bangsa seperti yang dulu dibangun oleh Bapak bangsa Indonesia seharusnya menjadi Visi bangsa kita, karakter yang menghormati dan adil terhadap sesama sehingga akhirnya di dalam tindakan nyatanya tidak melakukan tindakan stigma dan diskriminasi terhadap siapapun termasuk disabilitas dan kusta.
\end{abstract}

Kata kunci: kusta, sosial-kemasyarakatan, hubungan antarmanusia, stigma dan diskriminasi terhadap orang yang mengalami kusta 


\section{PENDAHULUAN}

Hari Kusta sedunia yang sudah dilaksanakan pada 29 Januari 2012 lalu sepatutnya kita rayakan dengan rasa keprihatinan yang sangat mendalam karena ternyata masalah Kusta dan Stigma/Diskriminasi yang mengikutinya belum lenyap di bumi Indonesia sampai sekarang. Namun tahun demi tahun penulis semakin sangat berbangga dengan peran serta masyarakat Indonesia khususnya Jakarta, Surabaya, dan Makassar serta Kupang dalam mengantisipasi hari kusta dunia yang selalu diperingati setiap minggu keempat bulan januari setiap tahunnya. Tepat bersamaan dengan hari kematian seorang pahlawan dunia dan india yang sangat dihormati yaitu: Mahatma Gandhi, pahlawan tanpa kekerasan yang mengangkat harkat martabat bangsanya dan khususnya orang yang mengalami kusta di india dan seluruh dunia tanpa memandang ras, agama, asal, suku dlsb. Representasi kelompok disabilitas di dalam proses berdemokrasi dan pengawasannya belum optimal apalagi maksimal, pengarusutamaan harus dilakukan disetiap lini di dalam pemerintahan, baik eksekutif, legislatif, yudikatif dan media massa atau press. Bagaimana memperkuat kelompok disabilitas untuk mengadvokasi transparansi perencanaan dan pengawasan penganggaran. Pendekatan yang hanya berfokus pada isu-isu karitatif bukan tujuannya, namun bagaimana isu-isu yang berhubungan dengan kesetaraan hak dengan yang lain harus terjadi. Jika tidak maka kaum disabilitas tidak memperoleh kesempatan yang setara, hendaknya isu disabilitas menjadi arus utama di setiap langkah dan tujuan pembangunan, sama dengan isu gender yang sudah mendahului sebelumnya.

Salah satu penyebab terjadinya kesenjangan dalam pemenuhan hak-hak penyandang disabilitas khususnya orang yang mengalami kusta adalah masih adanya anggapan bahwa disabilitas dan kusta merupakan persoalan kesejahteraan yang menjadi tanggung jawab Kementerian Sosial. Sementara itu, alokasi ketersediaan anggaran Kementerian Sosial untuk rehabilitasi sosial bagi penyandang disabilitas terbatas, karena itu dipandang mendesak untuk lebih melibatkan masyarakat yang lebih luas dalam mengantisipasi masalah-masalah yang berhubungan dengan kusta dan disabilitas menjadi arus utama. Disabilitas dan kusta tidak dapat dipisahkan karena memiliki keterkaitan yang sangat erat, apalagi dalam isu-isu yang berhubungan dengan stigma dan diskriminasi, hanya dalam tulisan ini penulis akan fokus kepada isu-isu yang berhubungan dengan kusta saja. Populasi penyandang Disabilitas yang menurut data SUSENAS 2004 dan PUSDATIN KESSOS yang sudah mencapai 2.126.785 juta orang. Memang banyak sekali data-data yang dapat kita pakai, namun salah satu yang dapat dipercayai adalah data-data yang diambil dari SUSENAS beberapa tahun lalu, secara spesifik memang belum ada data yang benar-benar valid mencapai sempurna. Penulis yakin jumlah ini sudah melebihi dengan sangat signifikan dalam tahun-tahun terakhir ini. Menurut informasi di atas, jumlah komposisinya sbb: Disabilitas Tubuh (717.312 jiwa), Disabilitas Mental (181.135 jiwa), Disabilitas Grahita (290.837 jiwa), Disabilitas Netra (338.672 jiwa), Disabilitas Rungu Wicara (375.036 jiwa), Disabilitas Ex Kusta (1.282.281 jiwa).

Pokok permasalahan dalam penelitian ini adalah kusta dan diskriminasi serta stigmatisasinya di Indonesia. Sedangkan rumusan masalah dalam penelitian ini adalah bagaimana masalah kusta dan diskriminasi serta stigmatisasinya di Indonesia serta bagaimana caranya untuk mengurangi masalah tersebut diatas dimulai dari pembangunan karakter manusia indonesia dan pengetahuan tentang disabilitas atau cacat.

\section{Tujuan, Kegunaan, dan Lingkup Penelitian}

Tulisan ini memaparkan tentang masalah kusta yang masih merupakan masalah besar dalam kehidupan berbangsa Indonesia. Membangun karakter bangsa seperti yang dulu dibangun oleh bapak bangsa Indonesia seharusnya menjadi visi bangsa kita, karakter yang menghormati dan adil terhadap sesama sehingga akhirnya di dalam tindakan nyata tidak melakukan tindakan stigma dan diskriminasi terhadap siapapun termasuk disabilitas dan kusta. Penulisan dan Penelitian ringkas ini diharapkan 
bermanfaat guna akan arti pentingnya mengetahui Masalah Kusta dan Diskriminasi serta Stigmatisasinya di Indonesia. Penelitian difokuskan dalam konteks kalangan awam misalnya mahasiswa, pemuda, dan remaja selain kalangan yang mengetahui tentang masalah-masalah sosial kemasyarakatan seperti dosen, aktivis lembaga swadaya masyarakat, professional, para pebisnis, dsb.

\section{Penjelasan Istilah}

Kusta adalah sejenis penyakit biologis, yang belakangan ini mungkin semakin sulit kita temukan para penderitanya di sekitar kita. Namun, fakta membuktikan bahwa penyakit ini masih ada sehingga tetap merupakan masalah kita semua. Adanya stigma yang melekat kuat pada diri penderitanya menyebabkan penyakit ini bersifat ganda: selain biologis, juga sosial. Penyakit kusta adalah suatu penyakit yang disebabkan oleh bakteri, namanya mycobacterium leprae. Penyakit ini menyerang kulit dan saraf tepi. Tanda-tandanya, muncul bercak-bercak putih di permukaan kulit dalam berbagai bentuk, sebagian besar berbentuk area yang berwarna keputihan (mirip panu). Bedanya, bercak tersebut tidak terasa apapun, bahkan mati rasa. Jadi, kalau digores atau ditusuk sampai berdarah, tidak akan merasakan sakit apa pun. Bila penyakit ini tidak segera diobati, maka perlahan-lahan kuman menyerang syaraf sehingga menimbulkan kerusakan. Kuman ini hanya menyerang saraf tepi, tidak menyerang otak atau sumsum tulang belakang. Daerah yang paling sering diserang kuman ini adalah saraf lengan bawah, tungkai bawah, dan wajah. Jikalau menyerang tangan, menyebabkan hilangnya rasa di telapak tangan, kelumpuhan jari-jari, dan terlihat sebagai jari kiting (claw hand), yakni keadaan jari-jari menekuk ke dalam dan tidak bisa diluruskan sehingga seakanakan dalam posisi mencakar. Jikalau menyerang kaki, menyebabkan hilangnya rasa di telapak kaki, bahkan kaki menjadi semper (foot drop), yakni pergelangan kaki tidak bisa diangkat ke atas sehingga mudah luka. Demikian halnya, jika menyerang wajah, maka terjadi kelumpuhan otot kelopak mata sehingga sulit menutup mata dengan benar. Penulis masukkan disabilitas sebagai isu Utama dan kusta isu khusus.

Hubungan antar sesama manusia, adalah kemampuan mengenali sifat, tingkah laku, pribadi seseorang. Dalam hal ini berusaha mencoba menemukan, mengidentifikasi masalah dan membahasnya untuk mencari pemecahan. Tujuannya adalah agar tercapai kehidupan yang harmonis yaitu masingmasing orang saling bekerja sama dengan menyesuaikan diri terhadap satu dengan yang lain (Wikipedia, 2012)

Stigma dan Diskriminasi terhadap orang yang mengalami Kusta, Sifat biologis penyakit tersebut boleh jadi dapat dikikis habis berkat adanya kemajuan ilmu kedokteran disertai perbaikan gizi dan sanitasi. Lain halnya dengan stigma, aspek tersebut sangat sulit terhapus dari lingkaran kehidupan seseorang karena ia bersifat sosial dan dikonstruksi oleh masyarakat. Ia mulanya adalah label (cap), bahwa si penderita kusta itu "berbahaya" bagi sesamanya, sebab kusta bisa menular, diturunkan kepada anak-anak, dan lebih celaka lagi penyakit kusta dianggap "akibat kutukan Tuhan”. Seiring perputaran waktu, label tersebut melekat kuat pada diri penderita kusta sehingga semakin sulit dilepaskan. Itulah stigma, yang membuat penyandang kusta menjalani hidupnya bagaikan terpenjara, bukan oleh tembok tebal dan jeruji besi yang kuat, melainkan oleh masyarakat. Artinya, karena stigma, penyandang kusta menjadi manusia yang terasingkan dari sesamanya, sehingga hidupnya hari demi hari tidak bermakna. Jangankan menjalin relasi sosial, untuk sekadar berinteraksi pun banyak orang enggan dan membatasi diri. Pada umumnya kusta melanda kaum marjinal dan miskin, oleh karena standar kehidupan mereka yang buruk, baik dari sisi sanitasi, gizi, atau kesehatan. Dengan demikian, dapat dipastikan semakin tinggi tingkat kemiskinan, semakin besar pertumbuhan penyakit kusta. Apalagi stigma dan diskriminasi masih melekat terhadap penderita kusta sehingga membuat mereka tersisihkan di dalam kehidupan masyarakat kita yang majemuk. Saat ini sedang diperjuangkan CRPD yang dapat mencakup kusta juga disamping isu-isu disabilitas atau cacat sebagai titik sentralnya, yang mendorong untuk terjadinya pengurangan stigma dan diskriminasi kusta. 


\section{METODE PENELITIAN}

Metode yang digunakan adalah metoda penelitian kualitatif. Penelitian kualitatif ini merupakan penelitian khusus objek yang tidak dapat diteliti secara statistik atau cara kuantifikasi, penelitian kualitatif biasanya digunakan meneliti peristiwa sosial, gejala rohani, dan proses tanda berdasarkan pendekatan nonpositivis. Misalnya, kehidupan masyarakat, sejarah, tingkah-laku, fungsionalisasi organisasi, gerakan sosial, keagamaan, atau hubungan kekerabatan. Penelitian ini akan menghasilkan data deskriptif berupa ucapan, tulisan, dan perilaku orang-orang yang diamati. Melalui penelitian kualitatif, peneliti dapat mengenali subjek dan merasakan pengalaman mereka dalam kehidupan sehari-hari. Ditujukan untuk mendeskripsikan dan menganalisis fenomena, peristiwa, aktivitas sosial, sikap, kepercayaan, persepsi, dan pemikiran manusia secra individu maupun kelompok. Penelitian kualitatif bersifat induktif. Artinya, peneliti membiarkan permasalahanpermasalahan muncul dari data atau dibiarkan terbuka untuk interpretasi.

Data dihimpun dengan cara pengamatan yang saksama, mencakup deskripsi dalam konteks yang mendetail disertai catatan-catatan hasil wawancara yang mendalam, serta hasil analisis dokumen lain. Dalam konteks penelitian yang dilakukan, penulis bertujuan mendapatkan pemahaman tentang kenyataan yang realistis melalui proses yang dinamakan proses berpikir induktif. Penelitian yang dilakukan nantinya hanya menghasilkan penemuan masalah yang dihadapi oleh masyarakat dengan berorientasi pada data lapangan dalam hal ini masukan dari masyarakat atau mahasiswa-mahasiswa yang penulis maksud. Atas dasar data empiris yang sudah didapatkan, diangkat suatu teori yang kadang kala berbeda atau berlawanan dengan grand theory yang digunakan penulis sebagai peneliti. Sampel atau purposive sampling dalam penulisan ini dilaukan dengan strategi sampling variasi maksimum. Metode pengumpulan data adalah wawancara mendalam, observasi partisipan, dan analisis dokumen.

\section{Teknik Pengambilan Sampel}

Istilah sampel yang penulis maksud dalam penelitian di sini tidak berarti menunjuk pada suatu polulasi, tetapi pada orang-orang yang merupakan unit analisis. Istilah yang biasa dipakai dalam penelitian kualitatif menggunakan informan sehingga ada sebutan informasi secara detail tentang bagaimana peneliti membangun sampel penelitian dengan mempertimbangkan: Kriteria pemilihan awal orang atau latar belakangnya; Prosedur untuk mencapai variasi maksimal dalam sampel, misalnya, orang atau latar belakang berbeda atau heterogen, dari yang penulis pilih adalah latar belakang berbeda, agama, suku, asal, ras, dan bahkan kewarganegaraan khususnya di komunitas anak muda Jakarta dan komunitas kusta; Bagaimana peneliti memperoleh akses pada orang atau latar ini, termasuk jika ada masalah-masalah yang mungkin peneliti hadapi dalam membangun sampel, penulis tetap memakai nama, namun jurusan dan asal tidak penulis berikan secara lengkap agar privasi mereka tetap terjaga. Penulis juga memberikan masukan tentang perjalanan dalam mengambil data yang diambil dari yang menulis masukan dengan tanpa melibatkan penulis terlalu jauh masuk kedalam prosesnya, sehingga akan terjadi masukan yang partisipatif dari yang memberikan masukan.

\section{Instrumen Penelitian}

Sama dengan diatas, peneliti memberikan formulir yang akan diisi oleh yang memberikan masukan. Tentunya dengan bahasa yang mudah dimengerti oleh yang memberi masukan.

\section{Teknik Analisa Data}

Terdapat beberapa macam pendekatan untuk menganalisis data kualitatif. Para pakar penelitian kualitatif (Glaser \& Strauss, 1967), yang pada mulanya mendeskripsikan suatu prosedur 
yang biasa disebut metode komparatif konstan (constant comparative method) kemudian dikembangkan oleh pakar penelitian kualitatif yang lain (Lincoln \& Guna, 1985). Peneliti harus menyajikan secara eksplisit dan tepat tentang prosedur yang digunakan. Peneliti harus jelas dalam mendiskusikan metode, menyampaikan secara detail apa-apa yang penting selanjutnya mereka lakukan dn mengapa demikian? Semua ini dilakukan dalam rangka meningkatkan ketepercayaan kerja peneliti dan pengetahuan orang-orang tentang penelitian khususnya penelitian kualitatif.

\section{HASIL DAN PEMBAHASAN}

Jika kita melihat situasi penyakit Kusta, Hansen, Lepra atau Leprosy di Indonesia saya kira masih banyak orang yang tidak menyangka bahwa penyakit ini benar benar masih ada dan belum hilang sama sekali keberadaannya. Bahkan menurut data yang saya dapatkan Kementerian Kesehatan dan WHO jumlah orang yang mengalami kusta setiap tahunnya bertambah sampai sekitar lebih kurang 17.000 orang, sedangkan dari Kementerian Sosial jumlah orang yang pernah mengalami kusta (data SUSENAS 2004 dan PUSDATIN KESSOS sudah mencapai 1,2 juta orang). Sekitar sepuluh tahun yang lalu sayapun memiliki pendapat yang sama. Akan tetapi setelah melihat kenyataan yang sungguh-sungguh nyata akhirnya pupuslah pemikiran saya yang tidak komprehensif itu. Kehadiran penyakit ini bukannya semakin menghilang atau berkurang akan tetapi hadir semakin banyak dibeberapa daerah di Indonesia ini. Kalau dulu orang hanya tahu Rumah Sakit Sitanala Tangerang dan sekitarnya sebagai zona penderita kusta di Jakarta sekitarnya maka saat sekarang ini tersebar kemana mana. Bahkan daerah sekitar Bekasi pun saya melihat banyak penderita kusta yang berdiri dan duduk di sudut sudut jalan.

Seperti situasi yang berkembang di bangsa kita ini, rekan-rekan yang mengalami kusta tersebut itupun tidak diakomodir dengan baik oleh masyarakat umum dan juga beberapa instansi, mereka dianggap sebagai orang yang perlu dikasihani, atau bahkan juga dihindari dalam artian tidak diberikan kesempatan untuk berapresiasi yang positif dalam hidup mereka. Kementerian Kesehatan dan Kementerian Sosial, serta beberapa penyandang dana dari luar negeri, dan beberapa organisasi internasional dan nasional memang sudah memberikan bantuan yang sangat signifikan, akan tetapi ini tidaklah cukup, perlu ada gerakan yang menyeluruh dan sifatnya 'leverage' atau mengungkit secara bersama sama. Ibarat seperti beberapa orang yang mengungkit batu akan lebih mudah (tentunya dengan panduan aba-aba dari instansi terkait) dibandingkan dengan mengungkit batu tapi sendiri sendiri dan tanpa aba-aba lagi. Adanya suatu political will yang kuat dari Pemerintah, menyeluruh dari Eksekutif, Legislatif dan Yudikatif beserta Press atau Media Massa.

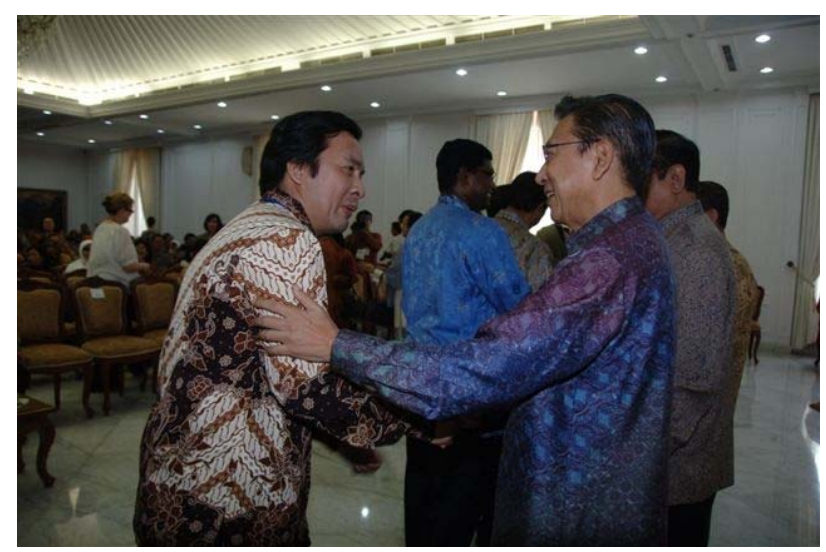

Gambar 1 Pentingnya dukungan dan political will pemerintah 


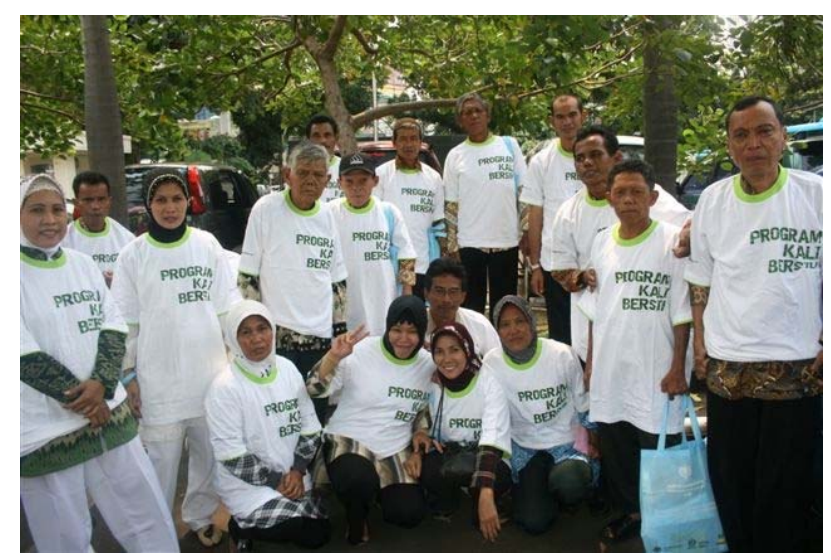

Gambar 2 Kebersamaan yang melibatkan komunitas kusta harus ada

Hal inilah yang sering menjadi suatu masalah yang sering terjadi di Indonesia, bukan saja pada masalah kusta akan tetapi pada penyakit penyakit menular lainnya. Memang kusta tidak sepopuler dengan flu burung, tuberkolosis, HIV-AIDS, dan sebagainya karena dianggap sudah penyakit kuno dan sudah mulai menghilang, bahkan didalam Millenium Development Goals (MDGs) isu kusta tidak dijelaskan dengan saksama namun digabung dengan konteks penyakit menular yang dilupakan dan masalah-masalah penyandang disabilitas. Perkiraan ini salah, karena ternyata penemuan kasus baru kusta setiap tahunnya masih tetap sama dan cenderung stabil dari tahun ke tahun. Di samping itu, kusta bukanlah penyakit yang mengakibatkan kematian, seperti penyakit menular lainnya, akan tetapi bisa dikatakan penyakit kronis. Yang banyak sekali menimbulkan masalah masalah sosial ekonomi bagi penderitanya, membuat banyak sekali lingkaran setan yang tidak habis-habisnya didalam kehidupan rekan-rekan yang mengalami kusta.

Kehadiran penyakit kusta di Indonesia memang masih akan tetap ada, peran masyarakat umumnya dan juga pemerintah beserta organisasi organisasi non-pemerintah diperlukan secara simultan. Tidak ada seorangpun yang dapat menyelesaikan masalah kusta ini secara sendiri-sendiri. Termasuk rekan-rekan yang sudah lama berkecimpung dalam masalah kusta ini. Dibutuhkan peran serta dari masyarakat yang sudah pernah mengalami dan yang sedang mengalami kusta berbicara secara terbuka didalam masyarakat itu sendiri, kita tidak boleh menafikkan mereka dari segala usaha kita didalam mengentaskan masalah kusta ini. Sayang selama ini kita kurang memberdayakan mereka secara saksama, perlu usaha usaha peningkatan kapasitas dan peran yang jelas dan terbuka bagi para penyandang disabilitas kusta pada khususnya. Tentunya orang yang pernah mengalami kusta yang memiliki motivasi yang berkarakter, maksudnya bukan karena motivasi insentif yang hanya berdasarkan uang dan materi yang sifatnya tidak akan kekal, dan juga bukan karena motivasi yang disebabkan ketakutan karena mereka tidak akan dapat penghidupan yang layak.

Akan tetapi, untuk mencapai usaha-usaha tersebut tidaklah mudah, karena ternyata stigmastigma yang terjadi didalam masyarakat kita dan juga penyandang disabilitas kusta juga masih besar. Di beberapa tempat bahkan sangat ekstrim, karena setiap langkah dari yang mengalami kusta dianggap sangat berbahaya dan akan menjangkitkan penyakit ini ke orang orang yang berada didekat mereka. Padahal penyakit ini adalah penyakit menular yang paling lambat menular dibandingkan dengan yang lain. Stigma inilah yang membuat masyarakat yang mengalami kusta hidup berkelompok, dan mengelompokkan dirinya, yang pada akhirnya malah membuat permasalahan akan semakin banyak dan menumpuk. Hanya sedikit persentase saja para penyandang disabilitas ini yang dapat mengembangkan diri mereka menjadi orang orang yang mandiri. Indonesia termasuk lamban dalam mengembangkan hal ini, apalagi kita sampai sekarang belum benar benar memerhatikan dan menjalankan undang-undang yang memiliki konsekwensi dalam menerapkan azas azas hak azasi bagi penyandang disabilitas. Mudah-mudahan dengan diratifikasinya UU Disabilitas oleh DPR akhir tahun 
lalu akan membawa perbedaan yang nyata dan positif bagi penyandang disabilitas terlebih khusus rekan-rekan yang mengalami Kusta. UU Disabilitas ini di Internasional dinamakan CRPD.

Penulis ambil contoh, dalam perencanaan design pedestrian di Jalan Thamrin dan Jalan Sudirman saja para perencana dan kontraktor tidak memerhatikan orang orang yang berjalan dengan kursi roda, tiang tiang yang menghalangi jalan jalan pedestrian, hanya sesuai apabila penyandang disabilitas tanpa kursi roda. Begitupula beberapa waktu yang lalu, bahkan di Istana Presiden RI pun tidak ada kamar mandi khusus penyandang disabilitas, sehingga menimbulkan kesulitan bagi mereka untuk keluar masuk kamar mandi. Ini masih merupakan contoh kecil akan betapa tidak pedulinya kita kepada orang orang penyandang disabilitas, apalagi para penyandang disabilitas kusta yang mungkin lebih menyedihkan dari disabilitas yang lain.

Ikatan Arsitek Indonesia (IAI), Himpunan Desain Interior Indonesia (HDII) dan Ikatan Arsitek Lansekap Indonesia (IALI) dibutuhkan perannya dalam mengembangkan ini lebih lanjut lagi sampai ketingkat yang lebih tinggi disamping peran peran dari departemen departemen pemerintah RI dan diperkuat LSM-LSM/ ORNOP lokal dan nasional. Sebenarnya hal ini sudah lama dikembangkan dalam diskusi dan wacana mahasiswa perencanaan dan desain ini, akan tetapi diperlukan "law enforcement"dan political will yang sangat kuat dan berani guna menghela ide ide ini sampai ketataran masyarakat yang paling bawah. Kita sebenarnya mampu, buktinya sosialisasi helm, sosialiasi pemakaian lampu sepeda motor siang hari di Jakarta yang dimulai di Surabaya dan mampu menekan angka kecelakaan kendaraan sepeda motor secara signifikan baik di Jakarta dan Surabaya, namun sekarang sudah melemah kembali. Masyarakat profesi lainnya juga bisa nimbrung disini, termasuk lembaga-lembaga eksekutif, yudikatif legislatif Indonesia, pengacara, partai politik, tokoh-tokoh agama dan masyarakat, Komnas HAM, lembaga-lembaga independen, dan juga pemerintah daerah dengan pendekatan kontekstual dan relevan.

Bangsa-bangsa diseluruh dunia sangat memerhatikan Indonesia untuk masalah ini, termasuk lembaga-lembaga yang berasal dari Australia, Inggeris, Jepang dan Belanda. Saya khawatir ini hanya berlaku untuk mereka akan tetapi tidak berlaku bagi kita, betapa menyedihkan kalau kita bersikap seperti itu. Himbauan yang sering didengung-dengungkan pemerintah yang diwakili departemen kesehatan tidak ditanggapi dengan baik dari seluruh elemen masyarakat karena dianggap tidak menarik dan tidak memiliki nilai yang besar seperti problem problem sosial dan ekonomi lainnya. Saya kira kita tidak perlu membuat suatu gerakan sosial yang terstruktur dan terorganisasi secara rigid atau kaku, yang dibutuhkan adalah suatu masyarakat yang bertransform secara signifikan dari hari ke hari. Memang peran hukum akan sangat mendukung, apalagi kalau dijalankan dengan penuh kesadaran dan bukan dengan penuh ketakutan. Kalau kita ingin menjadi bangsa yang mandiri, maka seharusnyalah kita mulai berfikir dan bertindak secara kreatif, karena sampai kapan bangsa-bangsa di dunia ini akan dapat membantu Indonesia? Maka diperlukan suatu tindakan yang seperti yang saya katakan diatas yaitu membuat titik ungkit yang akan dijalankan secara bersama sama dengan satu aba aba. Demikian harapan kita masing masing. Oleh karena itu dibutuhkan Pemimpin yang berani menerobos "kabut" itu.

Beberapa tulisan dibawah ini adalah masukan yang penting dalam konteks masalah kusta yang masih ada bersama kehidupan bangsa Indonesia. Lily Purba aktivis perempuan dan kusta mencoba memberikan masukan yang penting.

"Selama saya menderita kusta, saya cukup berani keluar dari perkampungan ini seperti ke pasar atau jalan-jalan keluar dan teman-teman saya juga banyak yang datang bermain ke rumah. Tetapi, masyarakat tidak mau menerima sikap saya yang terbuka, malah suami mencemburui saya, karena saya bergaul dengan orang luar." (kisah ibu "A" di perkampungan kusta dekat Rumah Sakit Averno, Singkawang, Kalimantan Barat) 


\begin{abstract}
"Anak perempuan saya sudah menikah. Syukurlah menantu saya dan keluarganya tidak tahu kalau saya sebagai ibunya pernah menderita kusta. Jangan sampai mereka tahu, sebab kalau mereka tahu anak saya pasti diusir dan diceraikan" Saya tidak tahu di mana dia berada sekarang. Saya juga berusaha untuk tidak menghubunginya walau saya rindu sekali untuk bertemu." (kisah ibu "B” di perkampungan kusta dekat Rumah Sakit Averno)

"Laki-laki penyandang kusta/cacat lebih mudah mencari istri yg "sehat/normal" dibandingkan penderita perempuan mendapatkan suami yang sehat/normal. Bagaimanapun, perempuan yang menderita penyakit kusta pasti mengalami kesulitan melayani suami yang normal. Masih bersyukur kalau bisa bersuamikan laki-laki yang sama-sama menyandang kusta”, komentar masyarakat awam dan juga beberapa orang komunitas kusta di Kalimantan Selatan
\end{abstract}

Ketakutan dan menghindar dari stigma. Itulah reaksi kebanyakan penyandang kusta bahkan pada orang yang sudah sembuh dari penyakit ini. Walau tidak ada data statistik pentandang kusta secara terpilah antara perempuan dan laki-laki, namun dari studi kasus di Aceh (Cut, 1998) ditemukan fakta bahwa jumlah penderita laki-laki lebih banyak dibandingkan perempuan (rasio 1,56 selama periode 1993-1997). Departemen Kesehatan juga menyatakan bahwa lebih banyak penderita laki-laki ketimbang perempuan. Hal yang sama terjadi di seluruh dunia, kecuali di beberapa negara Afrika.

Kusta bisa menyerang, baik laki-laki maupun perempuan, tetapi peran lingkungan, biologi, gizi, dan beberapa faktor lainnya turut menentukan tingkat kerentanan seseorang terhadap risiko terkena kusta. Kejadian yang dituturkan oleh ibu "A" di Singkawang adalah kejadian yang jarang terjadi di kalangan penderita kusta. Biasanya di daerah daerah endemik tinggi, laki-laki mempunyai mobilitas yang tinggi ketimbang perempuan, karena konstruksi sosial laki-laki adalah pencari nafkah keluarga.

Pada kebanyakan keluarga di Indonesia, perempuan mempunyai peran lebih dominan dalam hal kepedulian dan memelihara kesehatan anggota keluarga, namun keputusan tetap berada ditangan laki-laki sebagai kepala keluarga. Di Aceh perempuan lebih independen dalam hal mencari pengobatan untuk kasus-kasus yang ringan. Kita tidak bisa memandang secara umum bahwa semua penderita kusta sama saja. Perempuan dan laki-laki mempunyai perbedaan sikap, tingkah laku, persepsi, dan juga dampak dari penyakit kusta (gender differences). Oleh karena itu, perlakuan (treatment) terhadap penderita kusta juga harus disesuaikan. Misalnya, di dalam studi kasus Aceh, penderita kusta perempuan enggan datang atau menemui juru kusta laki-laki. Di berbagai daerah, perempuan lebih banyak menyembunyikan dirinya untuk mengurangi rasa malu maupun karena sikap negatif masyarakat.

Penyakit kusta adalah penyakit yang lekat dengan pandangan negatif dan diskriminasi, baik yang muncul dari dalam diri sendiri maupun dari masyarakat. Stigma merupakan predikat yang melekat, pembedaan (sosial dan fisik) yang tidak diinginkan yang merendahkan dan mendiskreditkan seseorang untuk diterima sepenuhnya di dalam masyarakat (Gofman, 1990). Stigma bisa berasal dan dipaksakan dari masyarakat, anggota keluarga maupun dari penderita kusta itu sendiri, misalnya menghindari kontak langsung hingga dikucilkan dan dibuang oleh masyarakat dari tempat tinggalnya. Stigma yang ada di dalam masyarakat membuat penyandang kusta hidup dalam ketakutan dan malu berada di tengah-tengah masyarakat. Di samping pelbagai nama tentang kusta yang menggambarkan betapa bahaya dan menjijikkannya penyakit ini. Hal lain, adanya pelbagai kepercayaan tentang asalusul penyakit ini menyebabkan para penyandang kusta merasa bersalah, pasrah, dan malu. Stigma yang bernuansa moral dan non-moral antara lain adalah: penyakit kusta, karena tindakan yang salah dari penderita kusta itu sendiri, misalnya karena salah makan jenis makanan tertentu, berhubungan seks dengan perempuan yg sedang menstruasi, dan sebagainya; penyakit kusta, karena guna-guna atau ilmu hitam yang dikirim oleh musuh; penyakit kusta diwariskan dari keluarga; penyakit kusta merupakan hukuman/kutukan dari Tuhan atas dosa-dosa yang dilakukan penderita; penyakit kusta sudah digariskan atau diterima sebagai nasib. 
Kusta bukan hanya penyakit biologis tetapi sarat dengan stigma sosial dan moral. Stigma bisa berbeda antara satu daerah dengan daerah lainnya, dari waktu ke waktu. Tingkat stigmatization bisa saja berbeda antara perempuan dan laki-laki, bahkan stigma bisa berubah seiring dengan perubahan status penyakit penderita dan posisi status sosial ekonomi penderita.

\begin{abstract}
"Bapak ini kerasan berada bersama kita, dia selalu datang ke perkampungan atau ke Rumah Sakit kusta. Untung dia orang berada, sehingga dia bisa diterima di keluarganya dan bisa ke mana-mana. Katanya dia tidak betah di rumah anaknya," tutur seorang pasien kusta menceritakan pasien dari etnis Tionghoa di Singkawang.
\end{abstract}

Berikut ini beberapa perbedaan sikap dan perilaku penderita kusta dan masyarakat.

\title{
Persepsi tentang Kusta
}

Hampir semua daerah tempat diadakannya diskusi kelompok tentang kusta yang diselenggarakan oleh lembaga swadaya masyarakat kusta (laporan pra lsm kusta), mengatakan bahwa kusta adalah penyakit yang disebabkan oleh kutukan Tuhan, keturunan, dan membahayakan. Persepsi masyarakat tentang kusta sangat dipengaruhi oleh nilai-nilai budaya setempat yang cenderung menyalahkan korban sehingga pasrah pada nasib. Biasanya untuk menghilangkan persepsi yang salah ini, diperlukan tokoh agama untuk melalukan kampanye. Sebagai contoh, di Kalimantan Selatan, sebuah poster gambar dan himbauan seorang kyai ternama bahwa penyakit kusta bisa disembuhkan, ternyata cukup efektif untuk membuat masyarakat tidak takut lagi terhadap penyandang kusta. Persepsi masyarakat terhadap penyakit kusta lainnya yang berkaitan dengan kesehatan reproduksi perempuan adalah kalau seorang laki-laki melakukan hubungan seks dengan perempuan yang sedang haid, maka dia akan terkena penyakit kusta (kusta dipakai untuk melanggengkan tabu yang ada di dalam masyarakat). Demikian halnya dengan bayi yang menyusui dari ibu yang menderita penyakit kusta.

\section{Status dalam Keluarga}

Penyakit kusta bisa dijadikan alasan pembenaran perceraian bagi pasangan suami istri. Seorang istri yang hidup bersama dengan suami penyandang kusta, cenderung pasrah dan tetap tinggal dengan suaminya atau keluarganya, kalaupun ada yg meninggalkan suaminya, hal itu dilakukan setelah melewati beberapa tahap proses perawatan. Sementara itu, jika penyandang kusta adalah perempuan, dia akan menganjurkan suaminya untuk mencari istri lagi untuk menghindari perceraian atau perasaan malu, karena tidak dapat melaksanakan perannya sebagai istri dan anggota masyarakat. Ini merupakan salah satu bentuk stigmatization atau stigmatisasi dari diri penyandang kusta itu sendiri. Selain itu pernah terjadi kasus ekstrim pada satu daerah di Kalimantan Barat ketika penyandang kusta laki-laki tidak bisa mencari nafkah lagi menaruh rasa curiga yang luar biasa terhadap istrinya karena berinteraksi dengan orang luar. Perasaan curiga yang berlebihan mendorongnya melakukan kekerasan fisik dan psikis terhadap istri yang merawat dirinya. Hal lain, anak perempuan penyandang kusta biasanya memiliki kesempatan menikah yang lebih kecil dibandingkan laki-laki.

\section{Deteksi Dini dan Pengobatan}

Petugas kesehatan atau juru kusta yang melakukan deteksi dini terhadap masyarakat sering kali tidak menyadari bahwa ketika seseorang dinyatakan leprosy suspect (baik karena tanda kecil maupun yang bisa terlihat dengan jelas seperti bengkak, luka, dan kecacatan), reaksi yang bersangkutan dan masyarakat cenderung negatif, misalnya malu dan mengucilkan diri dari masyarakat, atau mendapat perlakuan diskriminatif dari masyarakat karena stigma penyakit tersebut. Di India Tengah, perempuan lebih menderita akibat pengucilan dan penolakan dari masyarakat (Leprosy review). Mereka dianggap sebagai kelompok rentan secara sosial. Lebih lanjut, banyak 
penelitian mengungkapkan bahwa perempuan terkena dampak penyakit kusta yg lebih besar ketimbang laki-laki.

Pengalaman dan dampak kusta berbeda antara perempuan dan laki-laki karena pengaruh, struktur sosial, dan budaya. Adanya penyakit kusta sebenarnya tidak terlepas dari masalah kesenjangan jender yang terjadi di Indonesia, khususnya kesehatan dan penyakit. Misalnya, akses dan kontrol perempuan terhadap pelayanan kesehatan reproduksi. Batasan atau hambatan dalam menjalankan perannya di ranah publik dan domestik memengaruhi mobilitas perempuan penyandang kusta untuk mendapatkan pengobatan dan perawatan lebih lanjut. Oleh karena itu, tidak heran kalau perempuan penyandang kusta mengalami diskriminasi dan beban ganda, yaitu sebagai penderita dan sebagai perempuan.

\section{Sikap Petugas Kesehatan}

Acap kali petugas kesehatan masih memegang stereotip tentang penderita kusta perempuan dan laki-laki dalam memberikan pelayanan kesehatan. Laki-laki dipandang lebih mempunyai mobilitas tinggi sehingga harus mengambil obat walau aksesibilitasnya terhadap pelayanan kesehatan lewat Puskesmas atau Rumah Sakit rendah. Demikian juga dalam menentukan jadwal pertemuan kelompok, perempuan penyandang kusta mengalami banyak hambatan karena waktunya tidak sesuai dengan kegiatan domestiknya.

Di berbagai Puskesmas di Indonesia dengan keterbatasan fasilitas pelayanan, tidak disediakan ruang konsultasi dan pemeriksaan khusus. Penyandang kusta merasa tidak nyaman dan dipermalukan karena semua orang yang ada di ruang pemeriksaan akan mengetahui penyakitnya. Apalagi kalau petugas kesehatan yang bias jender memberikan nasihat yang berhubungan dengan status mereka. Oleh karena itu, tidak mengherankan kalau pasien kusta memilih untuk tidak datang ke Puskesmas atau memilih Puskesmas di desa lain yang masyarakatnya tidak mengetahui keberadaan mereka. Ini merupakan penyebab sulitnya petugas kesehatan melakukan memantau pengobatan di luar wilayah kerja mereka, karena keterbatasan dana.

Distribusi penyakit kusta bisa terjadi karena faktor etnik. Di Indonesia etnik Madura dan Bugis lebih banyak menderita kusta dibandingkan etnik Jawa dan Melayu. Identifikasi keterkaitan berbagai faktor ras, status sosial, kelas, pendidikan dengan relasi jender, akan meningkatkan pemahaman dan kemampuan kita untuk mencari pemecahan masalah kusta yang disebabkan oleh faktor-faktor tersebut (pendekatan baru dan intervensi yang perlu dilakukan). Pemahaman secara lebih luas juga dapat membantu kita untuk mempromosikan kesehatan dan pencegahan penyakit di dalam masyarakat.

Walaupun tidak bisa digeneralisasi tentang peran, tanggung jawab, dan kontribusi perempuan dan laki-laki di dalam masyarakat, pengaruh konstruksi sosial laki-laki dan perempuan dan interaksinya dengan relasi sosial lainnya, sangat memengaruhi persepsi tentang penyakit kusta, faktor risiko, manajemen pengobatan, akes, pemanfaatan pelayanan kesehatan, dan dampak penyakit terhadap kehidupan keluarga. Stigma dan stigmatization penyakit kusta, tidak saja bisa merugikan penderita kusta perempuan, laki-laki, dan keluarganya tetapi juga kita semua sebagai bagian dari masyarakat. Stigma melahirkan diskriminasi dan berbagai bentuk pelanggaran hak-hak asasi manusia. 

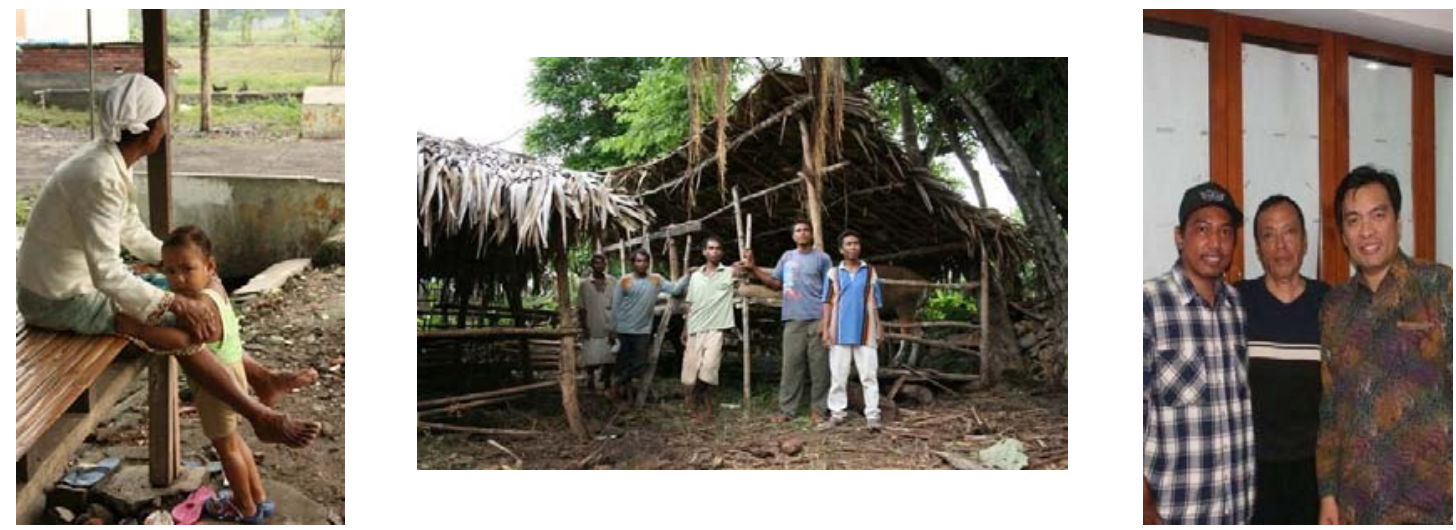

Gambar 3 Kusta sering menjadi sesuatu hal yang menakutkan bagi beberapa orang

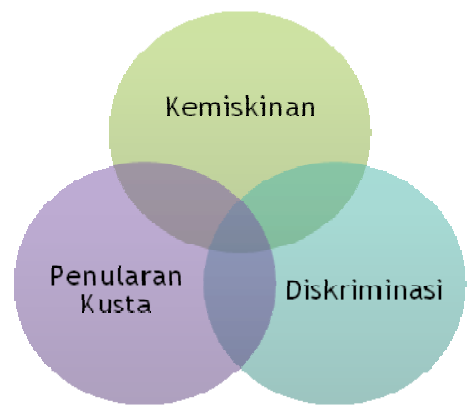

Gambar 4 Kondisi Kusta di Indonesia

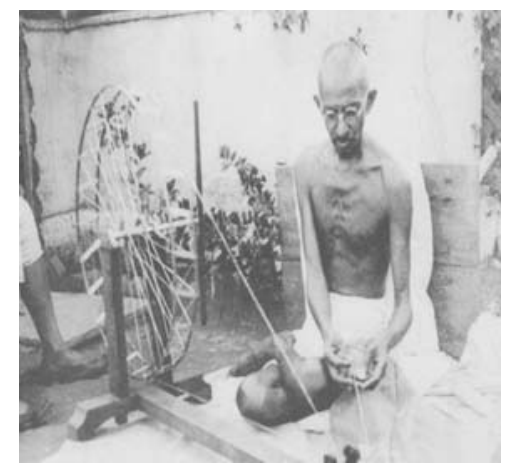

Gambar 5 Karakter seorang Gandhi yang menghilangkan stigma dan diskriminasi dengan karakternya

\section{SIMPULAN}

Memang masih banyak problem lain yang harus kita kerjakan dan agendakan sebagai bangsa dan rakyat Indonesia selama tahun 2012 ini ke depan. Sangat layak jika masalah kusta dijadikan agenda yang paling utama secara nasional. Akan tetapi, sebelum semuanya terlambat, alangkah baiknya kalau kita melihat penyakit, orang yang mengalami dan penyandang disabilitas ini serta dampak-dampak yang menyertainya apabila tidak ditangani secara dini khususnya lagi pada bagian Indonesia Timur seperti Maluku Utara, Papua, Irja Barat, NTT, Maluku, Jawa Timur, Sulawesi Selatan, dsb, mungkin ini adalah pembelajaran yang mungkin kecil dari suatu pemecahan 
permasalahan yang lebih besar lagi di masa depan. Adanya penyadaran diri dan upaya kita dalam menyelesaikannya dalam konteks nasional sangat dibutuhkan. Karakter yang baik adalah karakter yang menghormati hak siapapun, termasuk orang yang termarjinalisasi dalam konteks ini adalah kusta.

\section{Saran}

Penelitian yang ringkas ini belum menjawab secara lengkap dari yang terjadi sebenarnya masalah stigma dan diskriminasi di Indonesia, namun paling tidak dapat membangkitkan penelitian yang lebih mendalam lagi masa depan. Peran para intelektual dan masyarakat yang peduli disabilitas dan kusta secara khusus sangat dibutuhkan, agar masalah ini dapat diselesaikan dengan tuntas dimasa yang akan datang. Perlu ada kerja besar dan menyatu serta simultan dalam melakukannya sehingga tidak sporadis dilaksanakan oleh satu bagian masyarakat sipil saja, namun mencakup semua elemen masyarakat. Stigma dan diskriminasi terhadap disabilitas dan khususnya kusta sudah laten, dan perlu ada transformasi total, apalagi stigma dan diskriminasi terhadap anak dan perempuan yang sangat dalam. Sehingga terjadi multiple dan triple stigmatization. Karakter dan sikap adil dan fair harus dibangun, kita tidak boleh membedakan siapapun, Isu Disabilitas dan akhirnya kusta mempunyai keterkaitan antara satu dengan yang lain.

\section{DAFTAR PUSTAKA}

Adinda, T. (2011). Menggugat Kebijakan dan Pengadaan Fasilitas Umum untuk Difabel. Jakarta: Yayasan Jurnal Perempuan.

Amin, M. M. (2011). Pendidikan Karakter Anak Bangsa. Jakarta: Baduose Media.

Barliana, M. S. (2010). Arsitektur, Komunitas, Dan Modal Sosial. Bandung: UPI.

Bria, F. M. (2007). GISELA BOROWSKA - Kuabadikan Hidup Melayani Kaum Kusta dan Yatim Piatu. Jakarta: Praninta Jaya Mandiri.

Buku Pedoman Nasional Pengendalian Penyakit Kusta. (2007). Departemen Kesehatan RI Direktorat Jendral Pengendalian Penyakit dan Penyehatan Lingkungan.

Disability Rights Fund-Tides Foundation dan Sebayang, H. (2011). Panduan Advokasi Organisasi Penyandang Disabilitas Kepada Parlemen. DRF, Australia dan Indonesia.

Gea, A. A. (2005). Character Building II-Relasi dengan Sesama. Jakarta: Universitas Bina Nusantara - Gramedia.

Goldsmith, S., with PRP Architects. (2000). Universal Design-A Manual of Practical Guidances for Architects. Oxford, UK: Architectural Press.

Idawani, C., et all. (1998). Gender, Leprosy and Leprosy Control: A case study in Aceh Indonesia. , Netherland: Lera Stiching and KIT.

Kesuma, D. (2011). Pendidikan Karakter - Kajian Teori dan Praktik di Sekolah. Bandung: Remaja Rosdakarya.

Leprosy Review, Vol 71, Number 4, December 2000 
Muslich, M. (2011). Pendidikan Karakter-Menjawab Tantangan Krisis Multidimensional. Jakarta: Bumi Aksara.

Pascale A. P., Gyapong, M. The Gender Agenda in The Control of Tropical Diseases: A Review of Current Evidence.

Prayitno, dan Manullang, B. (2011). Pendidikan Karakter Dalam Pembangunan Bangsa. Jakarta: Grasindo.

Said, M. (2011). Pendidikan Karakter di Sekolah - What, How dan Why tentang Pendidikan Karakter. Surabaya: Jaring Pena.

Sinamo, J. (2006). Mengubah Pasir Menjadi Mutiara- Membangun Motivasi Akbar dan Mencetak Prestasi Unggul. Jakarta: Darma Mahardika Institut.

Sulhan, N. (2011). Panduan Praktis Pengembangan Karakter dan Budaya Bangsa-Sinergi Sekolah dengan Rumah. Surabaya: Jaring Pena. 